\title{
Editorial
}

\section{International real estate research}

\author{
Information is the religion of the modern world. David Lodge (2011)
}

When this journal was established at the Journal of Valuation back in 1982, all the papers published were from authors based in the UK. It was not an international journal even though the subscriptions included numerous, English speaking, institutions from outside the UK. Indeed, most of these were commonwealth countries and had a shared history of property education and practice.

In total, 37 years on and we are in a very different world. The majority of authors are now from outside the UK and the reach of the journal is now fully international covering all of the five (original) continents. The bulk of our papers now come from continental Europe and Asia with the number of North and South American papers now increasing substantially as well. In time, it is hoped that more African papers will be successful and then our journal will cover all real estate markets around the world.

This is important and the papers in this issue are a good reflection of the changes noted above. We have also just added 13 new members to our Editorial Board, from both academia and industry, reflecting the new geographical penetration of the journal.

On a personal note, this is really rewarding. When, in the early 1980s, I entered academia as a naive 22 year old on the faculty at The University of Reading in the UK, one of my ambitions was to expand the discipline of real estate around the world. Or, to be more precise, I wanted to create forums where academics and practitioners from around the world could present and debate their work on a global stage. I did this, with the support and help of many others, via journals such as The Journal of Property Investment \& Finance and The Journal of European Real Estate Research (which I was also instrumental in establishing) supported by the creation of international societies such as the European Real Estate Society and the International Real Estate Society. We now truly have many international forums and this can only be a good thing to encourage and support the next generation of academics and practitioners/researchers to cement the importance of real estate in the academic literature.

\section{Nick French}

\section{Reference}

Lodge, D. (2011), The Campus Trilogy: Changing Places; Small World; Nice Work, Penguin, p. 390.

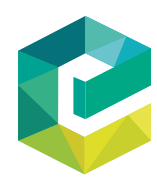

Journal of Property Investment \& Finance

Vol. 37 No. 5, 2019

p. 426

(C) Emerald Publishing Limited

1463-578X

DOI 10.1108/JPIF-08-2019-103 